\title{
A Response to Assessing the Role of Internal Motivation and Extrinsic Factors on Online Undergraduate Medical Teaching in a Resource-Poor Setting During Covid-19 Pandemic in North India: An Observational Study [Letter]
}

\section{Shubham Sharma \\ Faculty of Medicine, Imperial College, London, UK}

Correspondence: Shubham Sharma Faculty of Medicine, Imperial College, London

Tel +447802438995

Email shubham.sharmal6@imperial.ac.uk

\section{Dear editor}

I read, with great interest, the article by Dhingra et $\mathrm{al}^{1}$ that assesses the role of medical students' motivation and extrinsic factors on online teaching during the Covid-19 pandemic at a medical school in North India. Although the study is set in a specific context, as a medical student in the UK who has experienced online teaching, I can relate to the topic.

The study refers to three issues in respect of online teaching faced by students at a medical school in India relating to limited internet connectivity and students' socio-economic status and household environment. Similarly, in Pakistan, a lowincome country, internet connectivity issues and lack of faculty training and institutional support have been mentioned as being the key challenges in respect of online medical education during the pandemic. ${ }^{2}$

Although the authors ${ }^{1}$ conclude that students' household environment and socio-economic status hampered their motivation to attend online classes during the pandemic, these variables are not clearly defined or operationalized as has been done in some other studies. ${ }^{3}$ The authors also do not evaluate how students' socioeconomic status affects ownership of smart devices, access to internet and data.

This study uses online questionnaires, but poor internet connectivity in rural areas may have lowered the response rate. A combination of paper-based and online surveys $^{3}$ could have been used to address this issue. The sample ${ }^{1}$ only included 1 st, 2nd and 3rd year medical students, which limits generalizability of the results. Many studies have reported significant differences in student perception of online learning between students in pre-clinical ( 1 to 3 ) and clinical years (4 to 6), ${ }^{3,4}$ and highlighted limits of online learning in the clinical years. ${ }^{5}$ Another limitation is that this study ${ }^{1}$ is based at a single and relatively new medical school in North India, which further reduces its generalizability.

According to the study, ${ }^{1}$ students attending online classes from rural areas experience poorer internet connectivity. However, the sample is not stratified to control for this potentially confounding factor in the assessment of association 
between student motivation and internet connectivity. The authors recommend that the government should improve digital infrastructure to facilitate internet connectivity but do not outline the steps medical schools and the government could take to motivate students to attend online classes, for example, providing laptops, data and financial assistance and upgrading IT systems/platforms. ${ }^{3}$

The authors state that various factors limiting student motivation to attend online teaching should be considered for the desired student-led learning as mandated by competencybased medical education. ${ }^{1}$ I agree with their overarching conclusion that the amalgamation of online and traditional teaching should be used for educating medical students. It may be desirable to introduce such a hybrid teaching model in conjunction with Problem-Based-Learning (PBL) or Team-Based -Learning (TBL) approaches. ${ }^{5}$

In conclusion, despite its limitations this study raises many important issues which are relevant not only in resource-poor settings but also for richer countries such as the UK, where poor internet connection and family distraction have been found to be the commonly perceived barriers to access online teaching. ${ }^{5}$

\section{Disclosure}

The author reports no conflicts of interest in this communication.

\section{References}

1. Dhingra S, Pasricha N, Sthapak E, Bhatnagar R. Assessing the role of internal motivation and extrinsic factors on online undergraduate medical teaching in a resource-poor setting during Covid-19 pandemic in North India: an observational study. Adv Med Educ Pract. 2021;12:817-823. doi:10.2147/amep.s312812

2. Farooq F, Rathore FA, Mansoor SN. Challenges of online medical education in Pakistan during COVID-19 pandemic. $J$ Coll Physicians Surg Pak. 2020;30(6):67-69. doi:10.29271/jcpsp.2020.Supp1.S67

3. Alsoufi A, Alsuyihili A, Msherghi A, et al. Impact of the covid-19 pandemic on medical education: medical students' knowledge, attitudes, and practices regarding electronic learning. PLoS One. 2020;15 (11):e0242905. doi:10.1371/journal.pone.0242905

4. Bączek M, Zagańczyk-Bączek M, Szpringer M, Jaroszyński A, Wożakowska-Kapłon B. Students' perception of online learning during the COVID-19 pandemic. Medicine. 2021;100(7):e24821. doi:10.1097/md.0000000000024821

5. Dost S, Hossain A, Shehab M, Abdelwahed A, Al-Nusair L. Perceptions of medical students towards online teaching during the Covid-19 PANDEMIC: a national cross-sectional survey of $2721 \mathrm{UK}$ medical students. BMJ Open. 2020;10(11):e042378. doi:10.1136/ bmjopen-2020-042378

Dove Medical Press encourages responsible, free and frank academic debate. The content of the Advances in Medical Education and Practice 'letters to the editor' section does not necessarily represent the views of Dove Medical Press, its officers, agents, employees, related entities or the Advances in Medical Education and Practice editors. While all reasonable steps have been taken to confirm the content of each letter, Dove Medical Press accepts no liability in respect of the content of any letter, nor is it responsible for the content and accuracy of any letter to the editor.

\section{Publish your work in this journal}

Advances in Medical Education and Practice is an international, peerreviewed, open access journal that aims to present and publish research on Medical Education covering medical, dental, nursing and allied health care professional education. The journal covers undergraduate education, postgraduate training and continuing medical education including emerging trends and innovative models linking education, research, and health care services. The manuscript management system is completely online and includes a very quick and fair peer-review system. Visit http://www.dovepress.com/testimonials.php to read real quotes from published authors. 